\title{
Sowing Depth on Emergence of Different Safflower Genotypes (Carthamus tinctorius L.)
}

\author{
Natasha Barchinski Galant Lenz ${ }^{1}$, Reginaldo Ferreira Santos ${ }^{1}$, Maikon Lucian Lenz ${ }^{2}$, Luciene Tokura ${ }^{1}$ \\ \& Marinez Carpiski Sampaio ${ }^{1}$ \\ ${ }^{1}$ Western Paraná State University (UNIOESTE), Cascavel, Paraná, Brazil \\ ${ }^{2}$ Rua Flávio Sergio Rotta, 583, Cascavel, Paraná, Brazil \\ Correspondence: Natasha Barchinski Galant Lenz, Western Paraná State University (UNIOESTE), Cascavel, \\ Paraná, Brasil. Tel: 55-(45)-3220-3151. E-mail: nah.bio@gmail.com
}

Received: September 19, 2017

Accepted: October 23, 2017

Online Published: November 15, 2017

doi:10.5539/jas.v9n12p135

URL: https://doi.org/10.5539/jas.v9n12p135

The research is financed by Coordination for the Improvement of Higher Education Personnel (CAPES) and Araucária Foundation.

\begin{abstract}
The objective is to evaluate the germination of four different safflower genotypes at six sowing depths. The study was carried out in the experimental field of the Western Paraná State University, in Cascavel, in two stages: in protected environment and in the field. In a protected environment, the experimental units were vessels with a $0.10 \mathrm{~m}$ diameter and a $0.20 \mathrm{~m}$ height, maintaining a $0.05 \mathrm{~m}$ water level. Using 10 seeds per vase, filled with substrate composed of vermiculite and macronutrients. For the field, the experimental units were divided in 3 blocks with $1.50 \mathrm{~m}$ rows, with 30 seeds spaced in $0.05 \mathrm{~m}$, spacing between $0.30 \mathrm{~m}$ rows, totalizing blocks of $6 \mathrm{~m}$ by $1.8 \mathrm{~m}$. For the analysis, we performed a $5 \times 4$ factorial, with four replicates being 5 depths $(0.02 ; 0.04 ; 0.06$; 0.08 and $0.10 \mathrm{~m}$ ) and 4 genotypes, with analysis of percentage, speed index, mean time and average speed of emergence and morphometric characteristics of the plant. High emergence rates occurred for the lowest sowing depths, ranging from 60 to $80 \%$. At the greatest depths, the averages were below $50 \%$. At $0 \mathrm{~m}$ depth, there was no emergence for both sites. For the emergence speed index, the averages ranged from 0.47 to 1.34 seeds per day for the protected environment and 2.26 to 16.42 seeds per day for the field experiment. For both sites, the IMA-2103 genotype had the best performance for the evaluated indices. The depths indicated for planting are 2 and $4 \mathrm{~cm}$.
\end{abstract}

Keywords: energetic culture, field, genotypes, germination, protected environment

\section{Introduction}

Safflower (Carthamus tinctorius) has a high economic value due to the different forms of use as ornamental plant, edible and industrial oil, besides the use of its seed in the feeding of birds and ruminants and as medicinal herb (Mündel et al., 2004; Ekin, 2005).

Originated from Asia and Africa (Ashri \& Knowles, 1960; Dajue \& Mündel, 1996). The optimum temperature range for this oilseed crop varies from $20^{\circ} \mathrm{C}$ to $35^{\circ} \mathrm{C}$ (Coronado, 2010), requiring an average of 300-600 mm of rainfall per vegetative cycle (Emongor, 2010); however, the crop can take high periods of water deficit. Its production varies according to the availability of nutrients and water, but the average per hectare is from one to three tonnes with the population from 180 to 250 thousand plants (Vivas, 2002). Another advantage is that this seed has no dormancy (Dajue \& Mundel, 1996)

Although this crop is resistant to long periods of stress, it has the germination phase as the most sensitive; according to Mohammed, Benbella, and Talouizete (2002), the salinity in germination decreases the percentage and increases the average time. According to Mündel et al. (2004), another important fact is the high variation of the amount of seed put to germinate, which must be from 10 to $45 \mathrm{~kg} \mathrm{ha}^{-1}$, depending on the region, in order to guarantee the germination. 
After maturation, the seed goes through a period in which the embryo remains dormant. The resurgence of these activities is called germination and thus there is a growth that encompasses increase in number and size of cells and differentiation of tissues (Toledo, 1977). In this medium, seed tegument rupture occurs by the protrusion of one part of the embryo with subsequent emergence of the seedling in the soil (Borghetti \& Ferreira, 2004)

The recovery of seed growth for germination depends on many internal and external factors. Among the external factors, three are particularly important: water, oxygen and temperature (Raven, Evert, \& Eichhorn, 2001) and to determine these factors germination tests are used.

To understand better the quality of different seed lots or to evaluate the initial crop physiological aspects, these tests have been used as quick options and consist of subjecting seeds to various environmental factors and verifying their response. In this case, we can observe the causes of dormancy, morphological knowledge, to follow the development of the embryo and the seedling, determination of sowing rate among other factors (Carvalho \& Nakagawa, 2000; C. Baskin \& J. Baskin, 1998). There are also vigor tests, which can be performed together with the germination test, which provides estimates of seed performance (Bhering, D. C. F. Dias, Barros, L. A. S. Dias, \& Tokuhisa, 2003).

Among the factors studied for the germination test, sowing depth deserves attention because the germination needs to be fast and uniform. If sowing is very deep, seedling emergence becomes difficulty, increasing the possibility of pathogens attacking the seed. However, if the sowing is very shallow, it is exposed to animals, damages due to irrigation and exposure of the primary root (Cardoso et al., 2008; Marcos-Filho, 2005; Martins, Nakagawa, \& Bovi, 1999).

Therefore, the proper depth needs to be clearly defined, especially for the safflower culture that is new to the market and there are no adequate studies for this purpose. In order to provide knowledge about safflower in the early stages, this work aims to evaluate the emergence of four genotypes at different sowing depths.

\section{Method}

\subsection{Location of the Experiment}

The experiment occurred in a protected environment and in the field in the experimental area on the campus of the Western Paraná State University - UNIOESTE, in the city of Cascavel, Paraná, Brazil, latitude $24^{\circ} 53^{\prime} 47^{\prime \prime} \mathrm{S}$ and longitude $53^{\circ} 32^{\prime} 09^{\prime \prime} \mathrm{W}$. It is located in the third plateau of the state, in the western region of Paraná, with an average altitude of 785 meters and an area of $2,091 \mathrm{~km}^{2}$.

\subsection{Description of the Experiment and Experimental Design}

\subsubsection{Origin of Seeds}

The seeds were obtained in the Agronomic Institute of Paraná (IAPAR) in Cascavel - PR and in the Cotton Institute of Mato Grosso do Sul, in Cuiabá - MT.

\subsubsection{Protected Environment}

The experiment was conducted in a low-density polyethylene high tunnel greenhouse. The experimental units were made of $0.1 \mathrm{~m}$ diameter PVC pipes, $0.20 \mathrm{~m}$ high, housed in trays measuring $0.08 \mathrm{~m}$ in height, $0.31 \mathrm{~m}$ in width and $0.46 \mathrm{~m}$ in length, as Figures 2 . In order to maintain soil moisture, water was manually maintained in the tray, maintaining, from the beginning of the experiment, a $0.05 \mathrm{~m}$ water level.

To fill the tubes we used MecPlant commercial substrate, composed of vermiculite, bark of pinus, correctives of acidity and macronutrients, being a soil conditioner classified as " $\mathrm{F}$ ". It has water retention capacity of $60 \%$, cation exchange capacity of $200 \mathrm{mmol} / \mathrm{kg}$ and maximum humidity around $60 \%$.

The experiment was completely randomized, with a drawing for depths and genotypes. Seeding occurred with ten seeds in each tube, with six depths: $0 ; 0.02 ; 0.04 ; 0.06 ; 0.08 ; 0.10 \mathrm{~m}$, and four genotypes: IAPAR, IMA-2103, IMA-2232, and IMA-4409, with 4 replicates. The first experiment stage was conducted on May 10, 2016. After 16 days, the plants were thinned and only three plants were placed in each vase for them to develop until the 31 st day. 


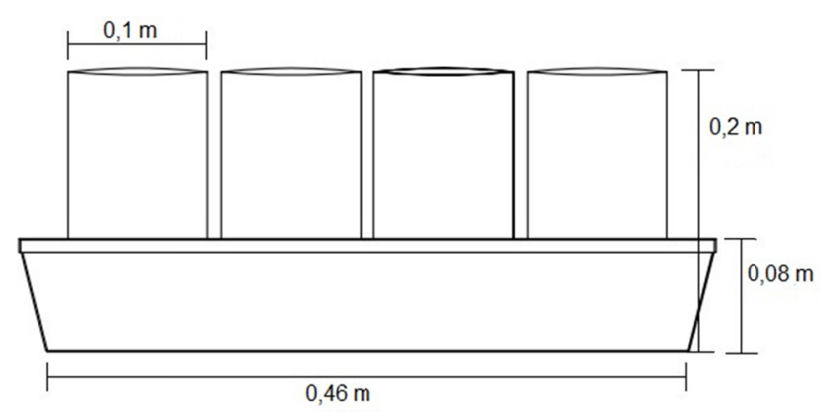

Figure 1. Representative scheme of experimental units

The microclimatic conditions of temperature and relative humidity were observed with a hygrometer, with daily scanning, represented in Figure 2.

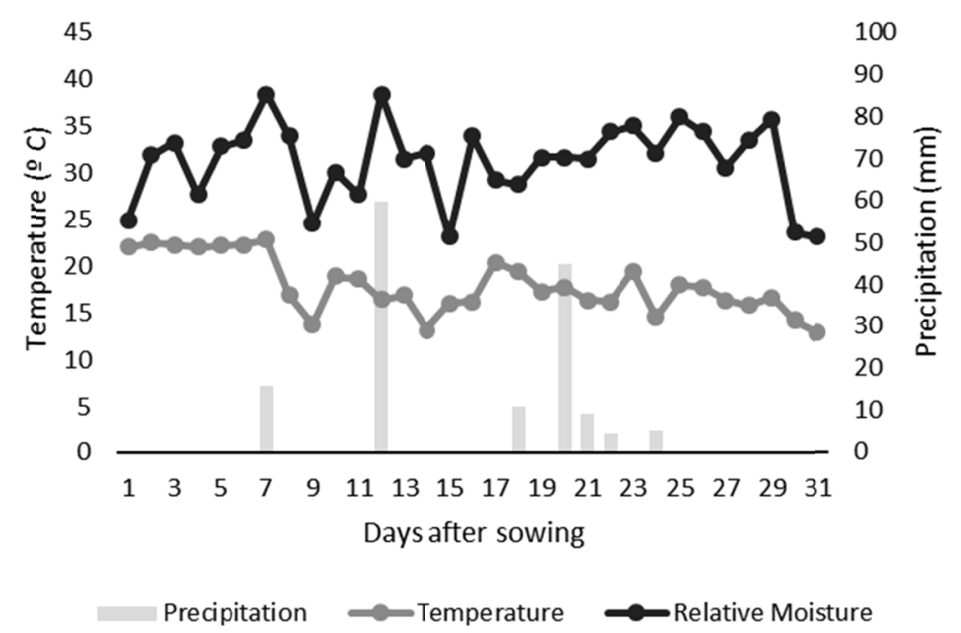

Figure 2. Environmental greenhouse conditions during the 31 experiment days, followed by means of temperature and relative humidity and precipitation

\subsubsection{In the Field}

The experiment occurred in the field in soil classified as Typical Distroferric Red Latosol (Brazilian Agricultural Research Corporation [EMBRAPA], 2014). Before using the soil, we prepared it by cleaning the soil with a machine, then manually cleaning existing weeds, and with no mineral fertilization. Figure 3 shows the water retention curve in soil, using samples collected in the three blocks at three different points in each block, in the 0 to $0.20 \mathrm{~m}$ layer, and later placed in the Richard's pressure chamber, which simulates a determined tension in the soil sample and subsequently, by weight difference, the water content related to the applied tension is determined. 


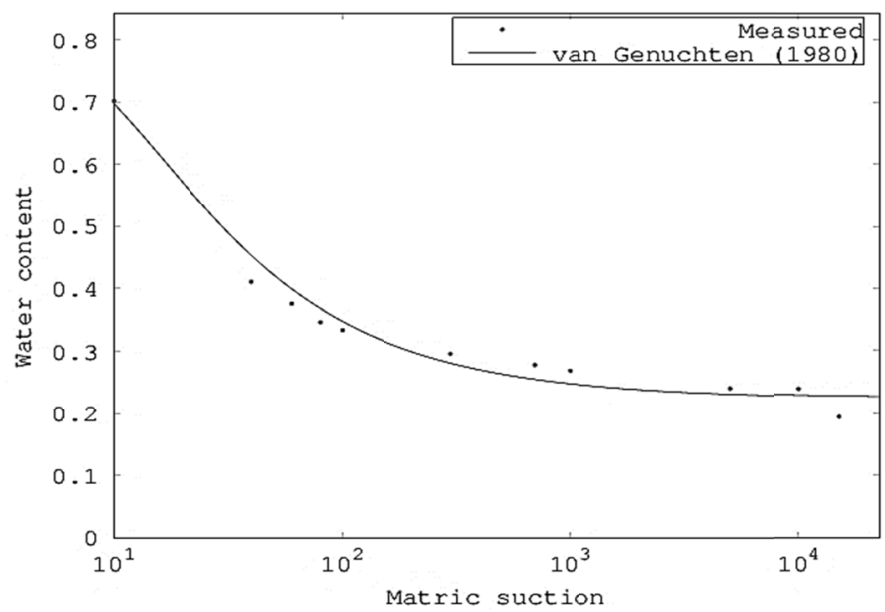

Figure 3. Water retention curve in soil, performed by software SWRC Fit

Source: Seki (2007).

Following the EMBRAPA (1997) methodology, consisting of using a 1 bar ceramic plate for low tensions from 0.01 to $0.1 \mathrm{MPa}$ and one of 15 bars for tensions of 0.5 and $1.5 \mathrm{MPa}$, distributing the soil collection rings on the plate, adding water to the ceramic plate, until the ceramic plate level is very close to the edge of the ring, leaving the samples in this condition for 24 hours for soil saturation. After this period, lightly tilt the plate in order to eliminate excess water and put in the Richards' extractor device.

The screws should be securely tightened and the pressure regulators opened gradually until the pressure manometer reaches the desired pressure, in this case 10, 40,60,80,100,300, 700,1,000, 5,000, 10,000 and $15,000 \mathrm{Kpa}$. At each applied voltage (always in ascending order), the sample is removed from the chamber after the drainage of the excess moisture (equilibrium between the applied tension and the related humidity) has ceased. Samples are weighed and returned to the pressure chamber by adjusting the next tension point. At the end of all applied tensions, humidity occurred. At the end of all tensions, the samples are taken to the oven at $105{ }^{\circ} \mathrm{C}$ for about 48 hours for apparent density and dry weight determination of the soil sample. Finally, the calculation for soil water determination is used:

$$
\text { Moisture }=100 \cdot \frac{a-b}{b}
$$

Where, a: the sample weight after being subjected to the used pressure; b: sample weight dried at $105^{\circ} \mathrm{C}$.

Thus, this retention curve is the expression between the matrix potential and the soil moisture content based on weight or volume (Gubiani, Reichert, Campbell, Reinert, \& Gelain, 2012). This is an important indicator of soil physical quality and is directly related to plants development (Debnath et al., 2012). Table 1 shows the chemical analysis of the soil.

Table 1. Chemical soil analysis results in the 0-0.2 m layer

\begin{tabular}{|c|c|c|c|c|c|c|c|c|c|}
\hline $\begin{array}{l}\mathrm{pH} \\
\left(\mathrm{CaCl}_{2}\right)\end{array}$ & $\mathrm{P}$ & K & $\mathrm{Ca}$ & $\mathrm{Mg}$ & $\mathrm{Al}$ & $\mathrm{H}+\mathrm{Al}$ & SB & $\mathrm{t}$ & $\mathrm{T}$ \\
\hline 5.33 & 5.18 & 0.17 & 5.67 & 2.24 & 0 & 3.19 & 8.08 & 8.08 & 12 \\
\hline
\end{tabular}

Note. SB: sum of bases $\mathrm{K}+\mathrm{Ca}+\mathrm{Mg}$, t: effective CEC and T: CEC to $\mathrm{pH} 7.0$.

Source: Agronomic Institute of Paraná - IAPAR (2016).

The experimental units consisted of $1.5 \mathrm{~m}$ rows for each genotype, with $0.3 \mathrm{~m}$ spacing between rows and $0.05 \mathrm{~m}$ seed spacing, totalizing a $6.0 \mathrm{~m}$ by $1.8 \mathrm{~m}$ block, as shown in Figure 4. Thus three randomized blocks were made; each block has 6 depths, with the 4 genotypes. 
For the sowing, there were 30 seeds per row, placed at $0.05 \mathrm{~m}$ distance, in the five depths: $0 ; 0.02 ; 0.04 ; 0.06$; 0.08 ; $0.10 \mathrm{~m}$, for the four genotypes: IAPAR, IMA-2103, IMA-2232 and IMA-4409. Implementing this second stage occurred on September 14, and was conducted until the plants completed 31 days.

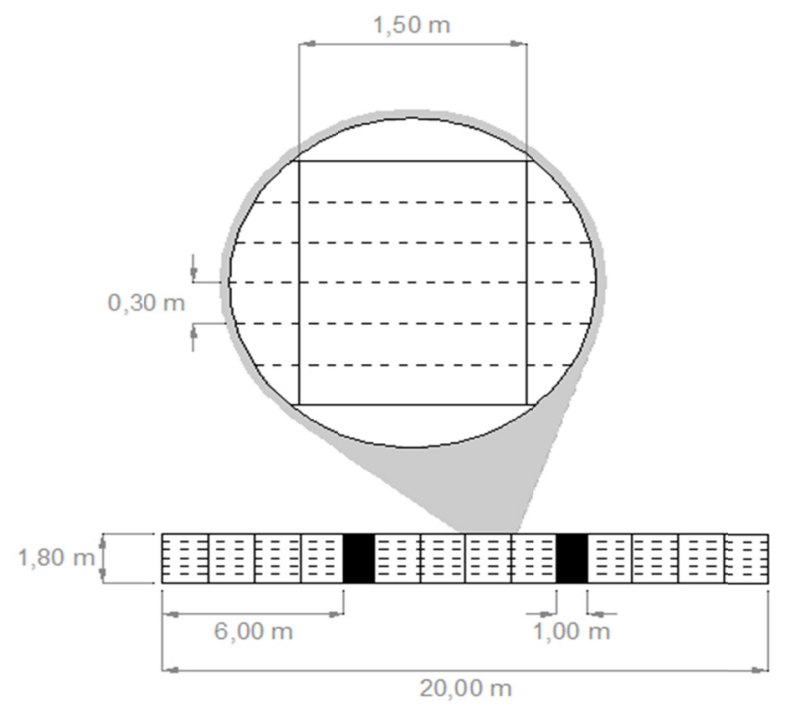

Figure 4. Representation of the field experiment, in which each block had 6 depths for each genotype

In order to replace water in the soil, the evaporation determinations were considered through a mini evaporimeter tank and the irrigation was performed with a drip system. In the first week, the irrigation was daily, and in the following week, the frequency was two days and from the third week until the final experimental period, the irrigation frequency changed to three days. To follow the water tension in the soil, six tensiometers were installed randomly, with daily scanning at 5 p.m. Figure 5 shows the soil moisture behavior during the long experimental period.

[I]

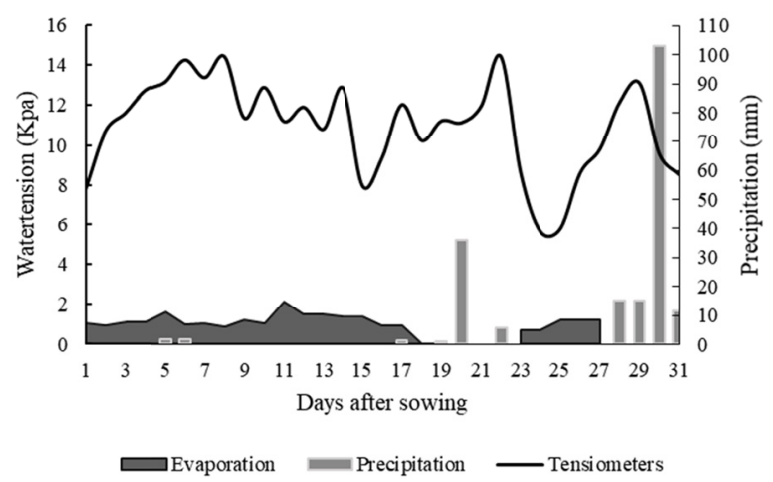

[II]

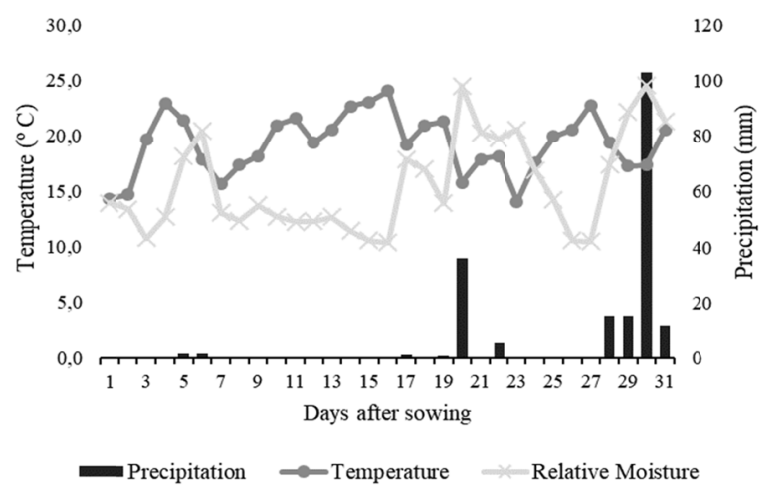

Figure 5. [I] Daily scanning of the tensiometers, together with the evaporation of the mini tank and the precipitations. [II] Environmental conditions during the experiment, demonstrating the average temperature, relative humidity and precipitation

Source: SIMEPAR, 2016.

\subsection{Evaluation of Safflower Plants}

The data analyzed for the protected environment and in the field were emergence percentage, emergence speed index, mean germination time, mean emergence speed, fresh and dry mass of plants, root and plant length, stem diameter. 
$>\quad$ Percentage of emergence (E): expressed as a percentage $(\%)$ :

$$
E=\frac{\text { Emergence seeds }}{\text { Total seeds }} \times 100
$$

$>$ Emergence speed index (ESI): proposed by Maguire (1962), expressed in seeds day ${ }^{-1}$ :

$$
\mathrm{EST}=\frac{\mathrm{E}_{1}}{\mathrm{~N}_{1}}+\frac{\mathrm{E}_{2}}{\mathrm{~N}_{2}}+\ldots \frac{\mathrm{E}_{\mathrm{n}}}{\mathrm{N}_{\mathrm{n}}}
$$

Where, $E_{1}, E_{2}, \ldots E_{n}$ : number of normal seedlings counted, in the first, second and last count. $N_{1}, N_{2}, \ldots N_{n}$ : number of days of sowing, in the first, second and last.

$>\quad$ Mean time of emergence (MTE): according to Laboriau and Valadares (1976), expressed in days:

$$
\operatorname{MTE}=\frac{\sum \mathrm{n}_{\mathrm{i}} \mathrm{t}_{\mathrm{i}}}{\sum \mathrm{n}_{\mathrm{i}}}
$$

Where, $n_{i}=$ number of germinated seeds in the interval between each counting; $t_{i}=$ time elapsed between the beginning of the germination and the i-th counting.

$>\quad$ Mean speed of emergence (MSE): expressed in days ${ }^{-1}$, by Carvalho and Carvalho (2009):

$$
\mathrm{MTE}=\frac{1}{\mathrm{t}}
$$

Where, $\mathrm{t}=$ mean time of emergence.

> Morphometric data: to collect the data in a protected environment, we used 1 plant per vase and for the field analysis, 4 samples per row were collected, that is, in each block 80 plants were collected. For measuring length of plant and root, we used an engineer's scale and for stem diameter, we used a digital caliper. The plants were stored in properly labeled paper bags, then weighed in a precision scale of $0.001 \mathrm{~g}$ for fresh mass determination and for dry mass, they were conditioned in a circulation oven with forced air at $65{ }^{\circ} \mathrm{C}$ for $72 \mathrm{~h}$ followed by subsequent weighing.

\subsection{Data Collection and Statistical Analysis}

The results were submitted to analysis of variance ANOVA and when significant, we compared means with the Tukey's test at 5\% probability, with the aid of the software SISVAR $®$ (Ferreira, 2011).

For both cases, there was no germination in the spread sowing $(0 \mathrm{~m})$. A completely randomized design was used in a $5 \times 4$ factorial scheme with 5 sowing depths $(0.02 ; 0.04 ; 0.06 ; 0.08 ; 0.10 \mathrm{~m}), 4$ genotypes (IAPAR, IMA-2103, IMA-2232 and IMA-4409) and 4 replicates.

For the greenhouse experiment, the emergence data were collected until the 13th day and in the field until the 16 th day with emergence stabilization. On the 31 st day, the plants were harvested for the other relevant analyzes.

\section{Results and Discussion}

\subsection{Controlled Environment}

There was no interaction between the depth and genotype factors for the response variables: emergence, speed index, mean time and mean speed of emergence. For this reason, we studied the isolated effect of depth and genotype for these variables, as shown in Tables 2 and 3. Since the interactions between genotypes and depths were not generally significant, they should be evaluated deeply and individually according to Perecin and Cargnelutti Filho (2008). In this case, there were representative results as shown in the graphs below.

The genotype IMA-2103 showed the highest emergence percentage, with $68 \%$ (Table 2), not statistically differing from IMA-2232 and IMA-4409, but only from IAPAR that obtained $42 \%$ of emerged grains, corroborating with Balashahri, Farhadi, Dohostais, Ghadiri and Rahimi (2013). 
Table 2. Mean values for emergence percentage (E), emergence speed index (ESI), mean time of emergence (MTE) and mean speed of emergence (MSE)

\begin{tabular}{|c|c|c|c|c|}
\hline Genotype & $\begin{array}{l}E \\
(\%)\end{array}$ & $\begin{array}{l}\text { ESI } \\
\left(\text { seeds day }{ }^{-1}\right)\end{array}$ & $\begin{array}{l}\text { MTE } \\
\text { (days) }\end{array}$ & $\begin{array}{l}\text { MSE } \\
\left(\text { days }^{-1}\right)\end{array}$ \\
\hline IAPAR & $42 \quad b$ & $0.54 \mathrm{c}$ & 0.79 & $1.18 \mathrm{~b}$ \\
\hline IMA-2103 & 68 & $1.12 \mathrm{a}$ & 0.68 & $1.54 \mathrm{a}$ \\
\hline IMA-2232 & $62.5 \mathrm{a}$ & $0.98 \mathrm{ab}$ & 0.74 & $1.39 \mathrm{ab}$ \\
\hline IMA-4409 & $57 \quad \mathrm{a}$ & $0.84 \mathrm{~b}$ & 0.69 & $1.32 \mathrm{ab}$ \\
\hline SLD & 14.94 & 0.22 & 0.15 & 0.25 \\
\hline VC (\%) & 31.16 & 30.84 & 26.07 & 22.32 \\
\hline $\mathrm{F}$ & $<0.01 * *$ & $<0.01 * *$ & $0.25^{\mathrm{ns}}$ & $<0.01 * *$ \\
\hline
\end{tabular}

Note. Averages followed by the same letter in the column do not differ by the Tukey's test at 5\% probability; *Significant at $1 \%$ probability; ${ }^{*}$ Significant at $5 \%$ probability; ${ }^{\text {ns }}$ non-significant at $5 \%$ probability by the $\mathrm{F}$ Test. SLD: Significant Least Difference; VC: Variation Coefficient.

Regarding the emergence speed index, the IMA-2103 had the highest average with 1.12 seeds per day, being statistically different from the others. The mean speed of emergence was also higher for the IMA-2103 (1.54 days), differentiating only from the IAPAR that presented a mean of 1.18 days, the mean time of emergence did not show differences between the averages.

The importance of evaluating different lots, varieties or genotypes in the laboratory is to have a germination pattern for each species, since each one has different characteristics for both physiological and germination behavior. Thus, it is possible to contribute to the generation of methods for the standardization of vigor and germination tests (Wielewicki, Leonhardt, Schlindwein, \& Medeiros, 2006; Abdo \& Paula, 2006). Low values of germination could indicate seed aging or deterioration (Godakahriz, Rastegar, \& Shahverdikandi, 2012). It is possible to observe this reaction in the IAPAR genotype.

Different depth levels significantly influenced the percentage of emergence (Table 3), in which the $0.10 \mathrm{~m}$ depth had $34.37 \%$ of the emerged seeds, contrasting the lower depth $(0.02 \mathrm{~m})$, which had $74.37 \%$ of the seeds emerged independently of the genotypes, corroborating with Dantas et al. (2011) who obtained averages of $70 \%$ for the safflower germination. From the results, the safflower better adapts to the conditions provided by sowing closer to the surface, according to Alves et al. (2014).

Table 3. Mean values for Emergence Percentage (E), Emergence Speed Index (ESI), Mean Time of Emergence (MTE) and Mean Speed of Emergence (MSE)

\begin{tabular}{lllll}
\hline $\begin{array}{l}\text { Depth } \\
(\mathrm{m})\end{array}$ & $\begin{array}{l}\mathrm{E} \\
(\%)\end{array}$ & $\begin{array}{l}\text { ESI } \\
(\text { seed day }\end{array}$ & $\begin{array}{l}\text { MTE } \\
(\text { days })\end{array}$ & $\begin{array}{l}\text { MSE } \\
\left(\text { days }^{-1}\right)\end{array}$ \\
\hline 0.02 & $74.37 \mathrm{c}$ & $1.34 \mathrm{D}$ & $0.61 \mathrm{a}$ & $1.67 \mathrm{c}$ \\
0.04 & $60.62 \mathrm{bc}$ & $1 \mathrm{C}$ & $0.73 \mathrm{ab}$ & $1.44 \mathrm{bc}$ \\
0.06 & $61.87 \mathrm{bc}$ & $0.86 \mathrm{bc}$ & $0.71 \mathrm{ab}$ & $1.42 \mathrm{bc}$ \\
0.08 & $55.62 \mathrm{~b}$ & $0.68 \mathrm{ab}$ & $0.83 \mathrm{~b}$ & $1.24 \mathrm{ab}$ \\
0.10 & $34.37 \mathrm{a}$ & $0.47 \mathrm{~A}$ & $0.75 \mathrm{ab}$ & $1.02 \mathrm{a}$ \\
\hline SLD & 17.78 & 0.26 & 0.18 & 0.3 \\
VC $(\%)$ & 31.16 & 30.84 & 26.07 & 22.32 \\
F & $<0.01^{* *}$ & $<0.01^{* *}$ & $0.03^{*}$ & $<0.01^{* *}$ \\
\hline
\end{tabular}

Note. Averages followed by the same letter in the column do not differ by the Tukey's test at 5\% probability; *Significant at $1 \%$ probability; **Significant at $5 \%$ probability; ${ }^{\text {ns }}$ non-significant at $5 \%$ probability by the $\mathrm{F}$ Test. SLD: Significant Least Difference; VC: Variation Coefficient.

Considering the emergence speed index values, Table 3 shows the highest number of seeds per day for the lowest depth $(0.02 \mathrm{~m})$ with 1.34 seeds per day followed by the $0.04 \mathrm{~m}$ depth with 1 seed per day, in which the greatest depth $(0.10 \mathrm{~m})$ obtained averages of 0.47 seeds day $^{-1}$, opposing the work of Abud, Reis, Innecco, and Bezerra (2010b), which did not obtain significant percentage difference, emergence speed index and mean time of 
emergence of safflower. Another significant factor for this circumstance is that the larger the seed sample placed to germinate, the higher the emergence speed index. For Cardoso et al. (2008) the reduction of emergence speed index occurs because in the deepest areas there is a higher $\mathrm{CO}_{2}$ concentration, thus promoting phytotoxic effects.

Taking into account the average time, the seeds that emerged faster were in the $0.02 \mathrm{~m}$ depth with a mean of 0.61 days. Therefore, the average speed was also higher for the $0.02 \mathrm{~m}$ depth, with 1.67 days $^{-1}$, that is, having the emergence faster when compared to the other depths. For good germination, it needs to be fast and uniform, followed by immediate emergence of the plants. However, this result is not always achieved especially if the sowing is very deep, which ends up making it difficult seedlings and increasing the period of susceptibility to pathogens. The higher the time spent in the early stages of development and the delayed emergence of soil, the more vulnerable the adverse conditions of the environment (Marcos-Filho, 2005; Martins, Nakagawa, \& Bovi, 1999).

By analyzing the genotypes in relation to the depth for the germination percentage (Figure 6[I]), there were high germination rates for the $0.02 \mathrm{~m}$ depth, with averages of $45 \%$ for the genotype IAPAR, $90 \%$ for IMA-2103, $87.5 \%$ for IMA-2232 and $75 \%$ for IMA-4409. For the $0.04 \mathrm{~m}$ depth, the genotype IAPAR remained with $45 \%$ of emergence, the genotypes IMA-2103 and IMA-4409 had the same percentage $(67.5 \%)$ and IMA-2232 obtained $62.5 \%$, with no statistical difference at the $5 \%$ level of significance. Corroborating with Jabeen and Ahmad (2013), who obtained $90 \%$ germination in a variety of safflower. For the $0.06 \mathrm{~m}$ depth, the IMA-2103 obtained the highest average of emergence rate with $87.5 \%$.
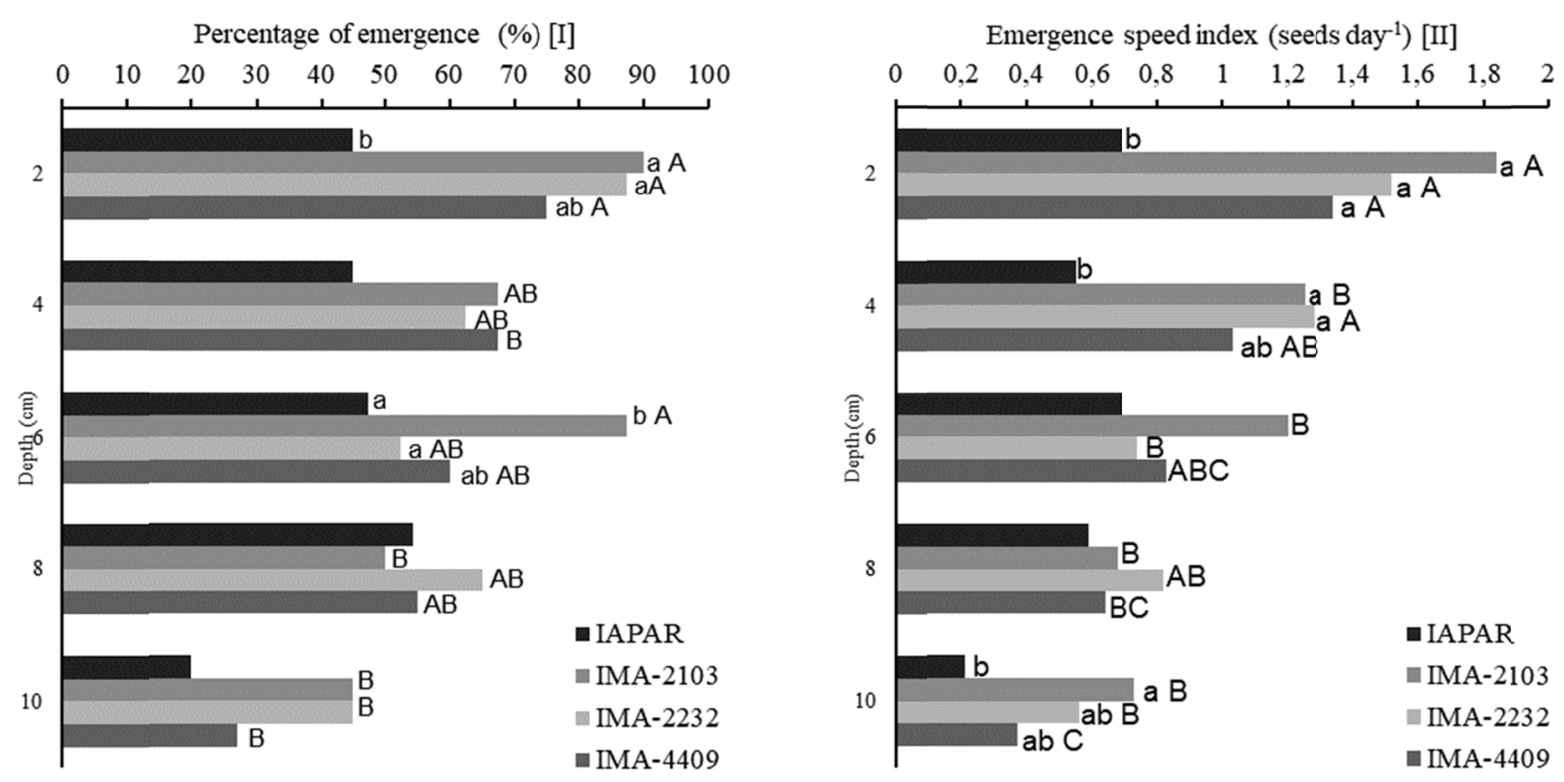

Figure 6. [I] Percentage of emergence and [II] Emergence speed index of the four safflower genotypes as a function of the five sowing depths, under protected environment

Note. Means followed by the same lowercase letter in each group of four genotypes do not differ from each other by the Tukey's test at 5\% probability. Means followed by the same capital letter in the same genotype color do not differ from each other by the Tukey's test at 5\% probability.

According to Mündel et al. (2004), in addition to adequate sowing depth, the high germination rate also depends on the amount of seed. According to the authors, the ideal for environments prone to drought is 10 to $15 \mathrm{~kg} \mathrm{ha}^{-1}$ and in rainier regions of 40 to $45 \mathrm{~kg} \mathrm{ha}^{-1}$. This is because, as observed in this study in the depths in which there was higher humidity, such as $0.08 \mathrm{~m}$ and $0.10 \mathrm{~m}$, there was a lower emergence rate.

At the $0.08 \mathrm{~m}$ and $0.10 \mathrm{~m}$ depths for all genotypes, their emergence percentage decreased, probably due to the physical barriers of the substrate, collaborating with Araldi et al. (2016). Observing the unfolding of the depths in relation to the genotype, there was no statistical difference for the genotype IAPAR. For the other genotypes, the highest average germination for the $0.02 \mathrm{~m}$ depth was observed, with $90,87.5$ and $75 \%$ for IMA-2103, IMA- 
2232 and IMA-4409, respectively. As for Luz et al. (2014) the highest emergence percentages were obtained in the shallower sowings.

In the initial plants development, the organic seed reserve is responsible for providing the nutrients for survival and development. This reserve is low in very small seeds, and if the plant depends solely on the seed reserves for a long time it may not be enough to sustain the new seedling until it is established and is self sufficient in the production of assimilated photo. Thus photosynthesis needs to start as soon as possible so that the seedling no longer depends on the reserves. The greater the sowing depth, the longer the seedling travel until the access to light, delaying this process (Taiz \& Zeiger, 1991; Mota et al., 2014). According to the observed in this work, safflower sowing is not recommended at $0.10 \mathrm{~m}$ depth.

Figure 6[II] shows that for the 0.02 depth the genotype IMA-2103 obtained 1.84 seeds emerged per day, which is statistically equivalent to the IMA-2232 and IMA-4409 indices. Corroborating with Bressan et al. (2016) that obtained safflower speed index not greater than 1.70 seeds per day. For the $0.04 \mathrm{~m}$ depth, the highest average was obtained with the genotype IMA-2232 with 1.28 seeds per day. At 0.06 and $0.08 \mathrm{~m}$ depths, there was no significant difference at 5\% probability. In this case, in both unfoldings, the IMA-2103 was better adapted to the conditions and was able to maintain high average in the five depths tested in this work. Da Silva et al., (2016) observed rates of 3.48 seeds per day for safflower also in a greenhouse at a $0.015 \mathrm{~m}$ depth.

The highest averages were obtained for the lowest depth, due to the rapidity of emergencies (Figure 7). Observing the genotypes, the highest averages were for the IMA-2103 from $1.94 ; 1.66 ; 1.54 ; 1.43 ; 1.16$ days $^{-1}$ to $0.02 ; 0.04,0.06 ; 0.08$ and 0.10 respectively. For the mean time of emergence, no significant differences were found at the 5\% confidence level. For Dantas et al. (2011) safflower under salt stress decreased about $50 \%$ of its germination and delayed the same index.

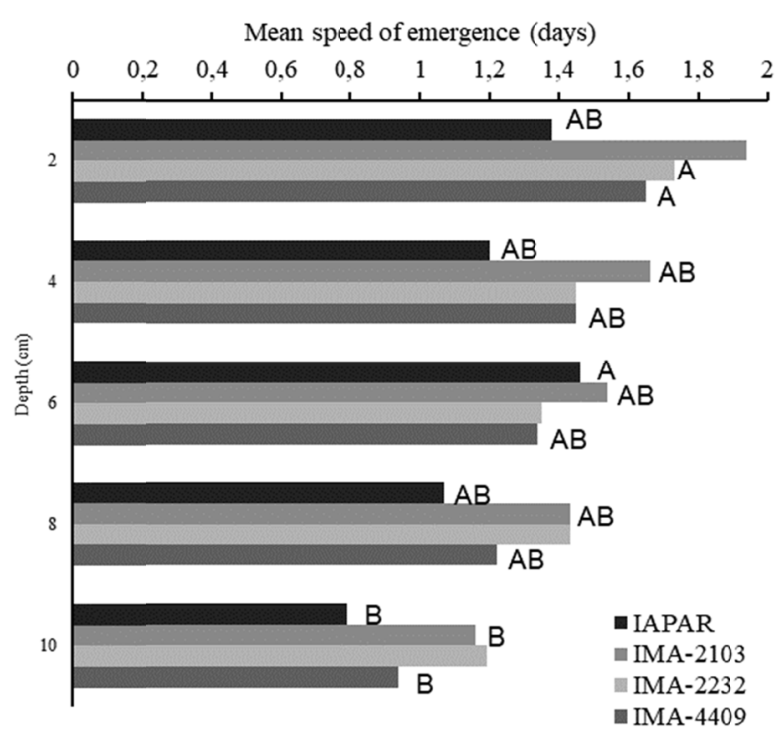

Figure 7. Mean speed of emergence (MSE) of the four safflower genotypes as a function of the five sowing depth

Note. Averages followed by the same lowercase letter and each genotype group at each depth do not differ from each other by the Tukey's test at 5\% probability. Means followed by the same capital letter in each color (genotype) do not differ from each other by the Tukey's test at 5\% probability.

Regarding morphometric data, Table 4 shows the statistical difference only for plant height, in which the IMA-4409 had the highest mean, with $0.1676 \mathrm{~m}$, followed by IMA-2103 $(0.1634 \mathrm{~m})$ and IMA-2232 $(0.161 \mathrm{~m})$ where the lowest average was for IAPAR $(0.1373 \mathrm{~m})$. One possibility of this little difference is the uniformity of the tested genotypes. 
Table 4. Averages of the morphometric characteristics of plant height (PH), stem length (SL), stem diameter (SD), fresh plant weight (FPW), fresh root weight (FRW) and fresh dry weight (FDW) for the genotypes

\begin{tabular}{|c|c|c|c|c|c|c|c|}
\hline Genotype & $\begin{array}{l}\mathrm{PH} \\
(\mathrm{m})\end{array}$ & & $\begin{array}{l}\text { SL } \\
(\mathrm{m})\end{array}$ & $\begin{array}{l}\text { SD } \\
(\mathrm{mm})\end{array}$ & $\begin{array}{l}\text { FPW } \\
\text { (g) }\end{array}$ & $\begin{array}{l}\text { FRW } \\
(\mathrm{g})\end{array}$ & $\begin{array}{l}\text { FDW } \\
\text { (g) }\end{array}$ \\
\hline IAPAR & 0.1373 & $\mathrm{~b}$ & 0.2411 & 2.8 & 1.76 & 1.14 & 0.12 \\
\hline IMA-2103 & 0.1634 & $\mathrm{a}$ & 0.2732 & 2.66 & 1.89 & 1.27 & 0.12 \\
\hline IMA-2232 & 0.161 & $\mathrm{a}$ & 0.2671 & 2.88 & 2.22 & 1.59 & 0.17 \\
\hline IMA-4409 & 0.1676 & $\mathrm{a}$ & 0.2751 & 2.88 & 2.1 & 1.53 & 0.11 \\
\hline SLD & 1.62 & & 4.74 & 0.41 & 0.54 & 0.65 & 0.09 \\
\hline VC (\%) & 12.38 & & 21.51 & 17.77 & 32.79 & 56.34 & 72.43 \\
\hline $\mathrm{F}$ & $<0.01 *$ & & $0.21^{\mathrm{ns}}$ & $0.45^{\mathrm{ns}}$ & $0.12^{\mathrm{ns}}$ & $0.23^{\mathrm{ns}}$ & $0.28^{\mathrm{ns}}$ \\
\hline
\end{tabular}

Note. Averages followed by the same letter in the column do not differ by the Tukey's test at 5\% probability; *Significant at $1 \%$ probability; ${ }^{*}$ Significant at $5 \%$ probability; ${ }^{\text {ns }}$ non-significant at $5 \%$ probability by the $\mathrm{F}$ Test. SLD: Significant Least Difference; VC: Variation Coefficient.

The morphometric data referring to the depths (Table 5) showed statistical differences only for plant height and dry weight. Disaccording with Rodrigues, Batista, Oliveira, Portella, and Souza (2016) that obtained statistical differences for the morphometric data analyzed in the different depths.

Table 5. Averages of the morphometric characteristics, plant height (PH), stem length (SL), stem diameter (SD), fresh plant weight (FPW), fresh root weight (FRW) and fresh dry weight (FDW) for the depths

\begin{tabular}{|c|c|c|c|c|c|c|c|c|}
\hline Depth & $\begin{array}{l}\mathrm{PH} \\
(\mathrm{m})\end{array}$ & & $\begin{array}{l}\mathrm{SL} \\
(\mathrm{m})\end{array}$ & $\begin{array}{l}\text { SD } \\
(\mathrm{mm})\end{array}$ & $\begin{array}{l}\text { FPW } \\
(\mathrm{g})\end{array}$ & $\begin{array}{l}\text { FRW } \\
(\mathrm{g})\end{array}$ & $\begin{array}{l}\text { FDW } \\
(\mathrm{g})\end{array}$ & \\
\hline 0.02 & 0.1698 & $\mathrm{a}$ & 0.247 & 2.8 & 2.07 & 1.28 & 0.14 & $a b$ \\
\hline 0.04 & 0.1617 & $\mathrm{a}$ & 0.2606 & 2.99 & 2.2 & 1.48 & 0.16 & $\mathrm{a}$ \\
\hline 0.06 & 0.159 & $a b$ & 0.2753 & 2.66 & 2.02 & 1.79 & 0.12 & $\mathrm{~b}$ \\
\hline 0.08 & 0.156 & $a b$ & 0.2701 & 2.83 & 2.01 & 1.28 & 0.17 & $\mathrm{a}$ \\
\hline 0.10 & 0.14 & $\mathrm{~b}$ & 0.2675 & 2.74 & 1.66 & 1.09 & 0.07 & $\mathrm{~b}$ \\
\hline SLD & \multicolumn{2}{|l|}{1.93} & 5.65 & 0.49 & 0.65 & 0.77 & \multicolumn{2}{|l|}{0.09} \\
\hline $\mathrm{VC}(\%)$ & \multicolumn{2}{|c|}{12.38} & 21.51 & 17.77 & 32.79 & 56.34 & \multicolumn{2}{|l|}{72.43} \\
\hline $\mathrm{F}$ & \multicolumn{2}{|c|}{$<0.01^{* *}$} & $0.66^{\mathrm{ns}}$ & $0.44^{\mathrm{ns}}$ & $0.22^{\mathrm{ns}}$ & $0.13^{\mathrm{ns}}$ & \multicolumn{2}{|l|}{$0.03^{*}$} \\
\hline
\end{tabular}

Note. Averages followed by the same letter in the column do not differ by the Tukey's test at 5\% probability; *Significant at $1 \%$ probability; **Significant at $5 \%$ probability; ${ }^{\text {ns }}$ non-significant at $5 \%$ probability by the $\mathrm{F}$ Test. SLD: Significant Least Difference; VC: Variation Coefficient.

The highest fresh dry weight values were at 0.04 and $0.08 \mathrm{~m}$ depths, while the lowest at $0.10 \mathrm{~m}$ depth. These results are in agreement with Silva and Cesarino (2016) who observed that the number of leaves, height and length of roots of Jutaí seedlings decreased linearly with the sowing depth increase.

From the emergence tests, the safflower showed a great germination potential, that at the lowest depths $(0.02$ and $0.04 \mathrm{~m})$ the germination is guaranteed with high percentages and greater speed in contrast to the deepest sowing $(0.08$ and $0.10 \mathrm{~m})$. It was not possible to obtain germination from the superficial sowing $(0 \mathrm{~m})$ for safflower cultivation.

\subsection{In the Field}

There was no interaction between the depth and genotype factors for the response variables: emergence, speed index, mean time and mean speed of emergence. For this reason, we studied the isolated effect of depth and genotype for these variables, as shown in Tables 6 and 7. As mentioned in the previous item, the indices were evaluated individually and had significant differences, shown in the following graphs.

There was no statistical difference between the percentage and the speed index (Table 6); however, the emergence values ranged from $63 \%$ to $58 \%$ and the speed index ranged from 7.55 seeds day ${ }^{-1}$ to the IMA-2232 up to 9.69 seeds day $^{-1}$ for the IMA-2103. Corroborating with Bottega et al. (2014), for Khomari, Soltani-Nezhad, and Sefghi (2014) the presence of salt made the germination of safflower species difficult, reducing the 
germination percentage and the chlorophyll percentage. According to Oba et al. (2015) among the different safflower lots, the highest germination percentage was $79 \%$, low germination percentages, below $47 \%$, are indicative of deteriorated seeds.

Table 6. Mean values for emergence percentage (E), emergence speed index (ESI), mean time of emergence (MTE) and mean speed of emergence (MSE) for the genotypes

\begin{tabular}{lllll}
\hline Genotype & $\begin{array}{l}\text { E } \\
(\%)\end{array}$ & $\begin{array}{l}\text { ESI } \\
(\text { seed day }\end{array}$ & $\begin{array}{l}\text { MTE } \\
(\text { days })\end{array}$ & $\begin{array}{l}\text { MSE } \\
\left(\text { days }^{-1}\right)\end{array}$ \\
\hline IAPAR & 63.77 & 8.57 & $4.05 \mathrm{ab}$ & $0.3 \mathrm{ab}$ \\
IMA-2103 & 60.44 & 9.69 & $3.23 \mathrm{~b}$ & $0.37 \mathrm{a}$ \\
IMA-2232 & 58.88 & 7.55 & $4.31 \mathrm{a}$ & $0.25 \mathrm{~b}$ \\
IMA-4409 & 60.88 & 8.41 & $4.05 \mathrm{ab}$ & $0.32 \mathrm{ab}$ \\
SLD & 16.1 & 3.26 & 0.901 & 0.111 \\
VC (\%) & 26.97 & 3.95 & 24.27 & 36.33 \\
F & $0.87^{\text {ns }}$ & $0.38^{\text {ns }}$ & $0.01^{* *}$ & $0.05^{*}$ \\
\hline
\end{tabular}

Note. Averages followed by the same letter in the column do not differ by the Tukey's test at 5\% probability; *Significant at $1 \%$ probability; ${ }^{*}$ Significant at $5 \%$ probability; ${ }^{\text {ns }}$ non-significant at $5 \%$ probability by the $\mathrm{F}$ Test. SLD: Significant Least Difference; VC: Variation Coefficient.

The mean time of emergence was faster for the IMA-2103, which obtained a mean of 3.23 days. The average speed was 0.37 days $^{-1}$. The highest emergence rate for the depth data was for sowing at $0.02 \mathrm{~m}(80.55 \%)$, corroborating with the work of Khodadad (2011) who obtained $81 \%$ of germinate safflower seeds. The $0.04 \mathrm{~m}$ depth had $77.22 \%$ of the emerged seeds, and the last depth $(0.10 \mathrm{~m})$ had the lowest average, $33.61 \%$. Disagreeing with the work of Silva et al. (2015), which obtained high germination rates $(91.6 \%)$ for sowing at 0.06 and $0.08 \mathrm{~m}$.

Table 7. Mean values for emergence percentage (E), emergence speed index (ESI), mean time of emergence (MTE) and mean speed of emergence (MSE) for depths

\begin{tabular}{|c|c|c|c|c|}
\hline $\begin{array}{l}\text { Depth } \\
(\mathrm{cm})\end{array}$ & $\begin{array}{l}E \\
(\%)\end{array}$ & $\begin{array}{l}\text { ESI } \\
\left(\text { seed day }^{-1}\right)\end{array}$ & $\begin{array}{l}\text { MTE } \\
\text { (days) }\end{array}$ & $\begin{array}{l}\text { MSE } \\
\left(\text { days }^{-1}\right)\end{array}$ \\
\hline 0.02 & $80.55 \mathrm{a}$ & $16.42 \mathrm{a}$ & $2.45 \mathrm{~d}$ & 0.46 a \\
\hline 0.04 & $77.22 \mathrm{a}$ & $12.93 \mathrm{a}$ & $2.68 \mathrm{~cd}$ & $0.39 \mathrm{ab}$ \\
\hline 0.06 & 63.88 ba & $7.17 \quad b$ & $3.62 \mathrm{bc}$ & $0.29 \mathrm{bc}$ \\
\hline 0.08 & $49.88 \mathrm{bc}$ & $3.99 \mathrm{bc}$ & $4.47 \quad \mathrm{~B}$ & $0.23 \mathrm{c}$ \\
\hline 0.10 & $33.61 \mathrm{c}$ & $2.26 \mathrm{~b}$ & $5.72 \mathrm{~A}$ & $0.18 \mathrm{c}$ \\
\hline SLD & 19.18 & 3.88 & 1.07 & 0.13 \\
\hline VC $(\%)$ & 26.97 & 38.95 & 24.27 & 36.33 \\
\hline $\mathrm{F}$ & $<0.01^{* *}$ & $<0.01^{* *}$ & $<0.01^{* *}$ & $<0.01^{* *}$ \\
\hline
\end{tabular}

Note. Averages followed by the same letter in the column do not differ by the Tukey's test at 5\% probability; *Significant at $1 \%$ probability; **Significant at $5 \%$ probability; ${ }^{\text {ns }}$ non-significant at $5 \%$ probability by the $\mathrm{F}$ Test. SLD: Significant Least Difference; VC: Variation Coefficient.

Regarding the emergence speed index, 0.02 and $0.04 \mathrm{~m}$ depths had the highest number of seeds emerged per day, 16.42 and 12.93 seeds day $^{-1}$, respectively. The $0.10 \mathrm{~m}$ depth had 2.26 seeds day ${ }^{-1}$. For the mean time and average speed, we also have a shorter time to the 0.02 and 0.04 depths. The behavior of the indices presented in the tables depends mainly on the reaction of the percentages of emergence, in which in this case, the 0.02 and $0.04 \mathrm{~m}$ depths stood out from the others.

For the emergence percentages (Figure 8[I]), the genotype unfolding in relation to the depth was not statistically significant. However, for of the depths with the genotypes, in the $0.02 \mathrm{~m}$ sowing, the four genotypes had germinations above $70 \%$, with emphasis on the IMA-4409 with $90 \%$ of the seeds emerging. Collaborating with 
the work of Siddiq, Ashraf, and Akram (2007) that obtained averages of $80 \%$ for the germination of a variety of safflower.
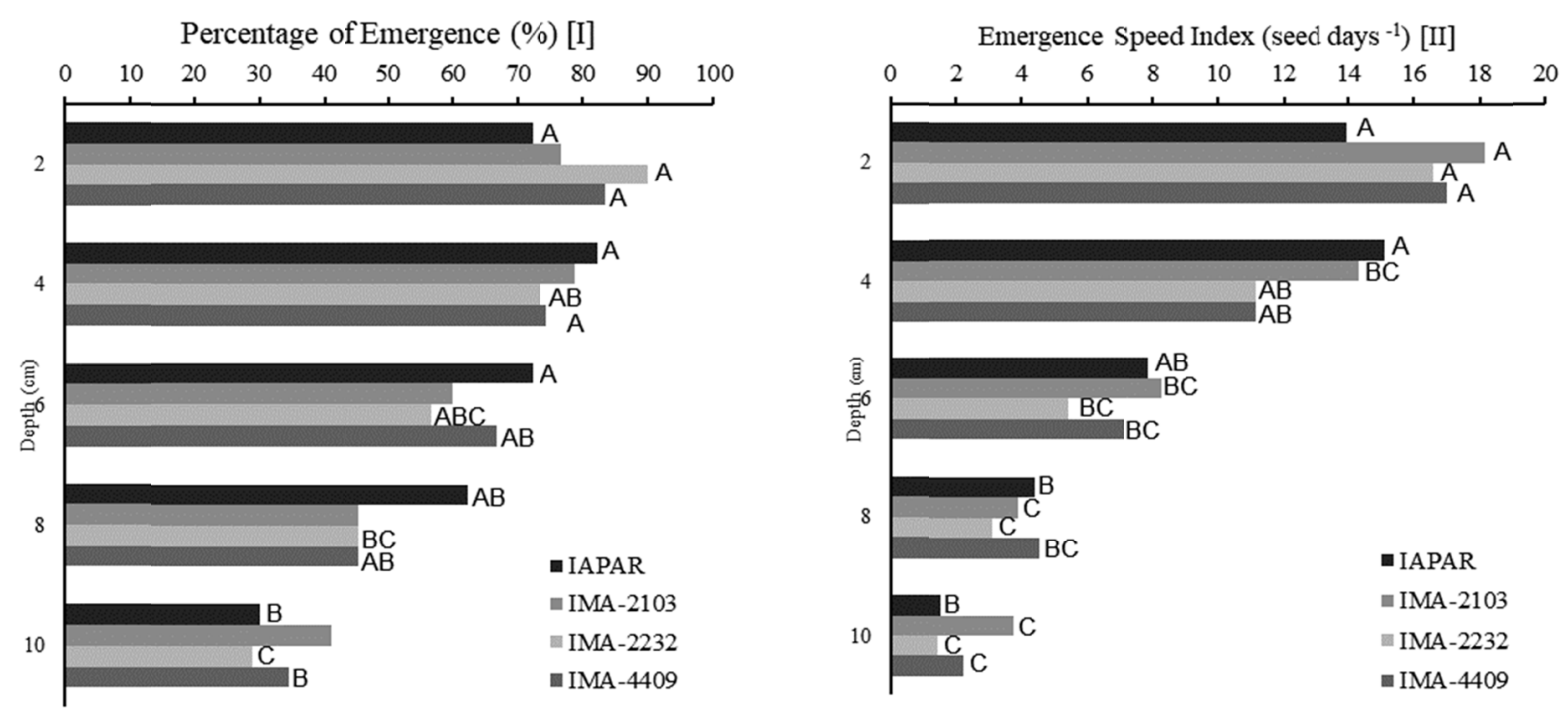

Figure 8. [I] Percentage of Emergence and [II] Emergence Speed Index (ESI) of the four safflower genotypes as a function of the five sowing depths

Note. Averages followed by the same capital letter in each color (genotype) do not differ from each other by the Tukey's test at $5 \%$ probability.

The depth also depends on the type of soil; in heavier soils or with poor drainage the seeds should be placed more superficially. In lighter or sandy soils, the seeds can be placed deeper, between 0.05 and $0.07 \mathrm{~m}$ to benefit from the higher moisture soil content. Karimi, Soheilikhah, Ghasmpour, and Zebardjadi (2011) state that in saline soils the percentage of safflower germination tends to decrease. The lowest emergence rate was for $0.10 \mathrm{~m}$ depth, ranging from $30 \%$ (IAPAR) to $43.33 \%$ (IMA-4409). For Carthamus oxyacantha M., the depths significantly affected its emergence; by increasing the depth from 0 to $0.06 \mathrm{~m}$ the percentage reduced to $35 \%$, having maximum germination at $0 \mathrm{~m}(72.50 \%)$ (Tanveer, Faried, Tahir, Javadi, \& Khaliq, 2012). For Limón and Peco (2016), the deeper the seed the lower its germination percentage.

Regarding the speed emergence index (Figure 8[II]) the depth of 0.02 and $0.04 \mathrm{~m}$ indicate averages between 13 to 17 seeds day ${ }^{-1}$ corroborating with Zuffo et al. (2014), which obtained higher speed index averages at $0.04 \mathrm{~m}$, and disagreeing with Silveira et al. (2016) observed emergence rates for safflower of 4.91 seeds day. According to Ávila, Braccini, Scapim, Martorelli, and Albrecht (2005), the seed lots that present higher values for the emergence speed index indicate greater vigor. In this case, the genotype indicated with greater vigor is IMA-2103, which holds the highest averages for this index for most depths.

Considering the mean time of emergence, Figure 9[I], the genotypes IMA-2103 and IMA-4409 developed faster, and obtained lower values for this index. According to Torabi, Soltani, Archontoulis, and Rabii (2016) safflower germination require from 18.7 to $250 \mathrm{~h}$, and germination is faster between $20-35^{\circ} \mathrm{C}$. 

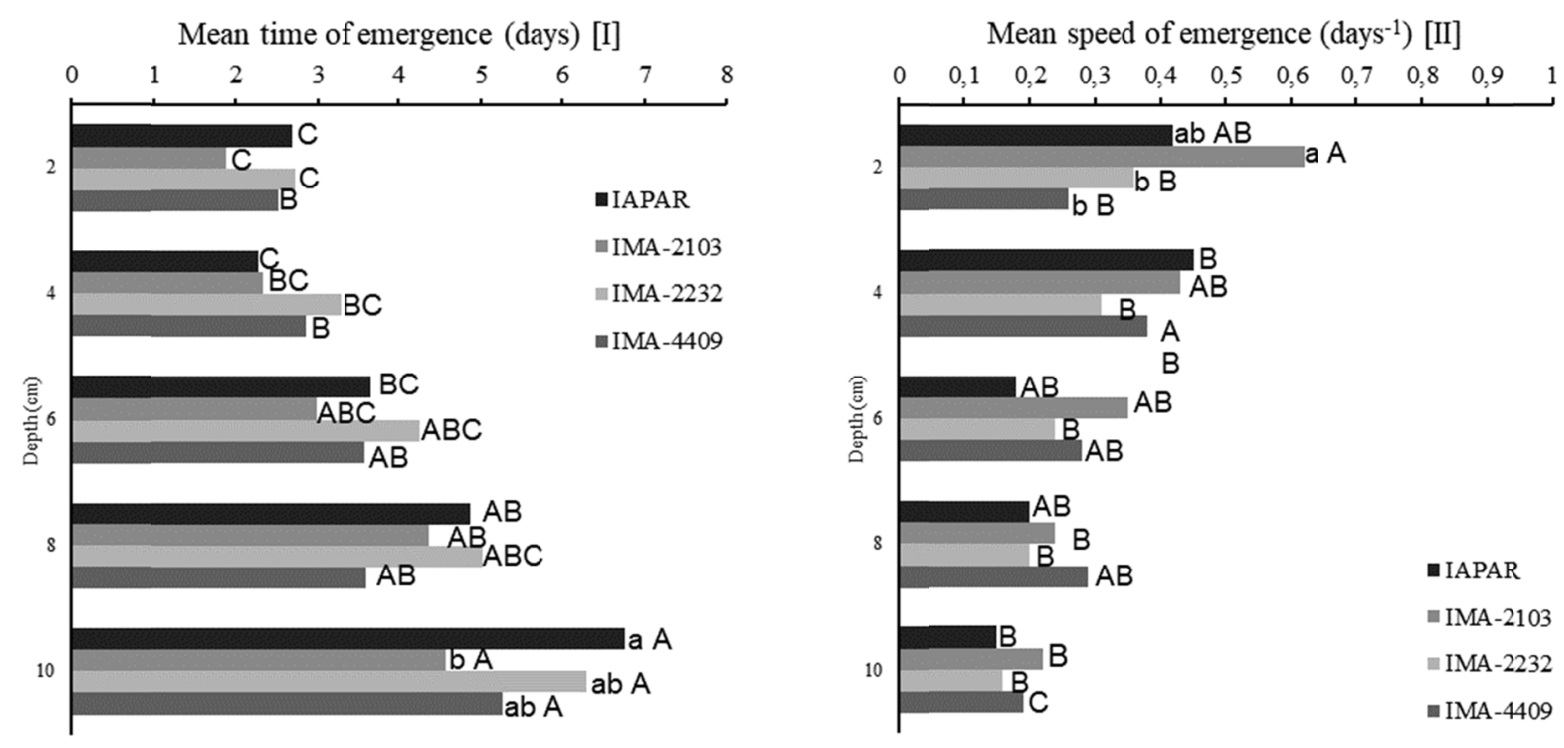

Figure 9. [I] Mean time of emergence and [II] Mean speed of emergence of the four safflower genotypes as a function of the five sowing depths

Note. Averages followed by the same lowercase letter and each genotype group at each depth do not differ from each other by the Tukey's test at $5 \%$ probability. Averages followed by the same capital letter in each color (genotype) do not differ from each other by the Tukey's test at 5\% probability.

The $0.02 \mathrm{~m}$ depth has the IMA-2232 with the lowest speed $\left(0.36 \mathrm{day}^{-1}\right)$ and higher for the IMA-2103 $\left(0.62\right.$ day $\left.^{-1}\right)$, and in the others there were no statistical differences for the mean speed of emergence, Figure 9[II]. For the genotypes, the IAPAR holds the highest speed for the $0.04 \mathrm{~m}$ depth $\left(0.45 \mathrm{day}^{-1}\right)$, for the IMA-2103, the highest speed is for the $0.02 \mathrm{~m}$ depth $\left(0.62 \mathrm{day}^{-1}\right)$, the IMA-2232 has the highest average for $0.02 \mathrm{~m}$ depth $\left(0.46 \mathrm{day}^{-1}\right)$. It was observed that the lower the moisture content for safflower, the longer it takes to germinate.

As for the morphometric variables for the genotypes, Table 8 shows no statistical differences among them. This could have occurred due to the similarity of the sizes and weights of the samples, obtaining no difference for the genotypes in these evaluated items. For Khomari, Soltani-Nezhad, and Sefghi (2014) in the absence of water, for the safflower germination, plant length and seed vigor indices decreased considerably. Santos et al., (2015) observed that the standard depth for sowing of the Urochloa species is from 0.021 to $0.0367 \mathrm{~m}$, resulting in greater phytomass accumulation of the seedlings.

Table 8. Averages of the morphometric data, plant height (PH), root length (RL), stem diameter (SD), fresh plant weight (FPW), fresh root weight (FRW) and fresh dry weight (FDW) for the genotypes

\begin{tabular}{lllllll}
\hline Genotype & $\begin{array}{l}\text { PH } \\
(\mathrm{m})\end{array}$ & $\begin{array}{l}\text { RL } \\
(\mathrm{m})\end{array}$ & $\begin{array}{l}\text { SD } \\
(\mathrm{mm})\end{array}$ & $\begin{array}{l}\text { FPW } \\
(\mathrm{g})\end{array}$ & $\begin{array}{l}\text { FRW } \\
(\mathrm{g})\end{array}$ & $\begin{array}{l}\text { FDW } \\
(\mathrm{g})\end{array}$ \\
\hline IAPAR & 0.1156 & 0.826 & 3.2 & 2.75 & 0.37 & 0.24 \\
IMA-2103 & 0.1127 & 0.782 & 3.26 & 2.64 & 0.32 & 0.22 \\
IMA-2232 & 0.1235 & 0.822 & 3.14 & 3.15 & 0.39 & 0.26 \\
IMA-4409 & 0.1135 & 0.786 & 3.19 & 2.22 & 0.35 & 0.18 \\
\hline SLD & 4.07 & 2.04 & 0.88 & 2.08 & 0.23 & 0.17 \\
VC (\%) & 35.77 & 25.97 & 28.26 & 78.92 & 65.6 & 75.21 \\
F & $0.88^{\text {ns }}$ & $0.9^{\text {ns }}$ & $0.98^{\text {ns }}$ & $0.69^{\text {ns }}$ & $0.90^{\text {ns }}$ & $0.62^{\text {ns }}$ \\
\hline
\end{tabular}

Note. Averages followed by the same letter in the column do not differ by the Tukey's test at $5 \%$ probability; ${ }^{*}$ Significant at $1 \%$ probability; ${ }^{* *}$ Significant at $5 \%$ probability; ${ }^{\mathrm{ns}}$ non-significant at $5 \%$ probability by the $\mathrm{F}$ Test. SLD: Significant Least Difference; VC: Variation Coefficient. 
The variables referring to the depths showed differences only for root length, Table 9 , where the largest length was observed for the samples of $0.10 \mathrm{~m}$ depth, with an average of $0.106 \mathrm{~m}$ and depth of $0.02 \mathrm{~m}$ averaging 0.681 $\mathrm{m}$. Demonstrating that up to 30 days, the safflower genotypes showed no apparent physiological differences. Corroborating with Maciel et al. (2012) who also did not obtain statistical differences for the different depths; however, disagreeing with Zuffo et al. (2014) who found statistical differences for the sowing of Brachiaria dictyoneura.

Table 9. Averages of the morphometric data, plant height (PH), root length (RL), stem diameter (SD), fresh plant weight (FPW), fresh root weight (FRW) and fresh dry weight (FDW) for the depths

\begin{tabular}{lllllll}
\hline Depth & $\begin{array}{l}\text { PH } \\
(\mathrm{m})\end{array}$ & $\begin{array}{l}\text { RL } \\
(\mathrm{m})\end{array}$ & $\begin{array}{l}\text { SD } \\
(\mathrm{mm})\end{array}$ & $\begin{array}{l}\text { FPW } \\
(\mathrm{g})\end{array}$ & $\begin{array}{l}\text { FRW } \\
(\mathrm{g})\end{array}$ & $\begin{array}{l}\text { FDW } \\
(\mathrm{g})\end{array}$ \\
\hline 0.02 & 0.1202 & $0.681 \mathrm{~B}$ & 3.13 & 2.65 & 0.35 & 0.21 \\
0.04 & 0.1303 & $0.782 \mathrm{ab}$ & 3.46 & 3.03 & 0.39 & 0.25 \\
0.06 & 0.116 & $0.765 \mathrm{ab}$ & 3.33 & 2.79 & 0.34 & 0.24 \\
0.08 & 0.1129 & $0.832 \mathrm{ab}$ & 3.28 & 2.8 & 0.39 & 0.25 \\
0.10 & 0.1022 & $0.106 \mathrm{a}$ & 2.79 & 2.18 & 0.3 & 0.18 \\
\hline SLD & 4.85 & 2.43 & 0.88 & 2.48 & 0.27 & 0.2 \\
VC (\%) & 35.77 & 26 & 28.26 & 78.92 & 65.6 & 75.21 \\
F & $0.57^{\text {ns }}$ & $0.03^{*}$ & $0.43^{\text {ns }}$ & $0.89^{\text {ns }}$ & $0.86^{\text {ns }}$ & $0.87^{\text {ns }}$ \\
\hline
\end{tabular}

Note. Averages followed by the same letter in the column do not differ by the Tukey's test at $5 \%$ probability; *Significant at $1 \%$ probability; $* *$ Significant at $5 \%$ probability; ${ }^{\text {ns }}$ non-significant at $5 \%$ probability by the $\mathrm{F}$ Test SLD: Significant Least Difference; VC: Variation Coefficient.

The different genotypes had little influence on statistical differences. However, for the depths, sowings at 0.08 and $0.10 \mathrm{~m}$ depths showed few percentages of safflower seedlings, reaching $33 \%$, suggesting that during this period seed deterioration could have occurred. Consequently, the indices evaluated later are impaired and decreased. When sowing is double or triple the seed size (as in the case of 0.02 and $0.04 \mathrm{~m}$ sowings), the crop reacts quickly, with high percentage of emergence $(90 \%)$, high seed rates per day and consequently higher average time and average speed, demonstrating that these two depths are more favorable for safflower sowing. Thus, we could not observe germination the throwing sowing $(0 \mathrm{~m})$ because most of the seeds were lost by the wind or by predators and those that remained did not germinate.

\section{Conclusion}

(1) In both experiments, the Genotype IMA-2106 had higher averages for emergence (68 and 60.44\%), emergence speed index (1.12 and 9.69 seeds day $\left.^{-1}\right)$, mean time of emergence ( 0.68 and 3.23 days) and mean speed of emergence ( 1.54 and 0.37 day $\left.^{-1}\right)$;

(2) The culture obtained higher results for the 0.02 and $0.04 \mathrm{~m}$ depth, being this one indicated for the safflower planting.

(3) Superficial or spread $(0 \mathrm{~m})$ sowing is not recommended because in both cases there was no germination, and in the field the seeds were lost by wind and predators.

(4) In both situations, no interaction between the genotype and depth factors was observed.

\section{Acknowledgements}

The first author thanks the Coordination for the Improvement of Higher Education Personnel (CAPES) and Araucária Foundation for granting a scholarship. Special thanks to Dr. Deonir Secco for all the help to carry out this work. And all the coauthors involved in the process.

\section{References}

Abdo, M. T. V. N., \& Paula, R. C. (2006). Temperaturas para a germinação de sementes de capixingui (Croton floribundus Spreng-Euphorbiaceae). Revista Brasileira de Sementes, 28, 135-140. https://doi.org/10.1590/ S0101-31222006000300020 
Abud, H. F., Reis, R. G. E., Innecco, R., \& Bezerra, A. M. E. (2010). Emergência e desenvolvimento de plântula de cártamos em função do tamanho das sementes. Revista Ciência Agronômica, 41, 95-99. https://doi.org/ $10.5935 / 1806-6690.20100013$

Alves, M. M., Alves, E. U., Silva-Moura, S. S., Araújo, L. R., Silva, R. S., \& Ursulino, M. M. (2014). Emergência e crescimento inicial de plântulas de Platymiscium floribundum Vog. em função de diferentes posições e profundidades de semeadura. Ciência Rural, 44, 2129-2135. https://doi.org/10.1590/ 0103-8478cr20120406

Araldi, D. E., Yamashita, O. M., Carvalho, M. A. C., Campos, O. R., Roque, C. G., \& Dallacort, R. (2016). Efeito da profundidade de semeadura e presença de palha sobre o substrato na emergência de Crotalaria juncea. Ambiência Guarapuava, 12, 525-538.

Ashri, A., \& Knowles, P. F. (1960). Cytogenetics of safflower Carthamus L. species and their hybrids. Agronomy Journal, 52, 11-17. https://doi.org/10.2134/agronj1960.00021962005200010004x

Ávila, M. R., Braccini, A. L., Scapim, C. A., Martorelli, D. T., \& Albrecht, L. P. (2005). Testes de laboratório em sementes de canola e a correlação com a emergência das plântulas em campo. Revista Brasileira de Sementes, 27, 62-70. https://doi.org/10.1590/S0101-31222005000100008

Balashahri, M., Farhadi, R., Dohostais, R. M., Ghadiri, I., \& Rahimi, M. (2013). Evaluation of cardinal temperatures and germination response to temperature in Safflower (Carthamus tinctorius L.) medicinal plant. Journal of American Science, 9, 56-60.

Baskin, C. C., \& Baskin, J. M. (1998). Ecologically meaningful germination studies. In C. C. Baskin \& J. M. Baskin (Eds.), Seed: Ecology, biogeography and evolution of dormancy and germination (pp. 5-26). New York: Academic Press. https://doi.org/10.1016/B978-012080260-9/50002-6

Bhering, M. C., Dias, D. C. F., Barros, D. I., Dias, L. A. S., \& Tokuhisa, D. (2003). Avaliação do vigor de sementes de melância (Citrullus lunatus Schrad.) pelo teste de envelhecimento acelerado. Revista Brasileira de Sementes, 25, 1-6. https://doi.org/10.1590/S0101-31222003000400001

Borghetti, F., \& Ferreira, A. G. (2004). Interpretação de resultados de germinação. In A. G. Ferreira \& F. Borghetti (Eds.), Germinação: Do básico ao aplicado (pp. 209-222). Porto Alegre: Artmed.

Bottega, E. L., Braido, R., Piazzetta, H. von L., Neto, A. M. O., \& Guerra, N. (2014). Efeitos da profundidade e velocidade de semeadura na implantação da cultura do milho. Pesquisa agropecuária Pernambucana, 19, 74-78. https://doi.org/10.12661/pap.2014.011

Bressan, R. T., Da Silva, R. F., Pilatti, M. A., Muller, F., Silveira, L., Silva, J. R., ... Lewandoski, C. F. (2016). Influence of Ilex paraguariensis aqueous extract on safflower growth and germination in vitro. African Journal of Agricultural Research, 11, 4021-4026. https://doi.org/10.5897/AJAR2016.11400

Cardoso, E. A., Alves, E. U., Bruno, R. L. A., Alves, A. U., \& Silva, K. B. (2008). Emergência de plântulas de Erythrina velutina em diferentes posições e profundidades de semeadura. Ciência Rural, 38, 2618-2621. https://doi.org/10.1590/S0103-84782008000900034

Carvalho, N. M., \& Nakagawa, J. (2000) Sementes: Ciência, Tecnologia e Produção (4th ed.). Jaboticabal: FUNEP.

Coronado, L. M. (2010). El cultivo del cártamo (Carthamus tinctorius L.) en México. Ciudad Obregon: SGI.

Da Silva, R. F., Bressan, R. T., Zilli, B. M., Pilatti, M. A., Souza, S. N. M., \& Santos, R. F. (2016). Allelopathic effect of aqueous extract of fresh leaf castor beans (Ricinus communis L.) applied to the beginning stage of soy (Glycine max L.) and safflower (Carthamus tinctorius L.). African Journal of Agricultural Research, 15, 2787-2793. https://dx.doi.org/10.5897/AJB2016.15707

Dajue, L., \& Mündel, H. H. (1996). Safflower (Cartamus tinctorius L.): Promoting the conservation and use of underutilized and neglected crop. Rome: IPGRI: International Plant Genetic Resource Institute.

Dantas, C. V. S., Silva, I. B., Pereira, G. M., Maia, J. M., Lima, J. P. M. S., \& Macedo, C. E. C. (2011). Influência da sanidade e déficit hídrico na germinação de sementes de Carthamus tinctorius L. Revista Brasileira de Sementes, 33, 574-582. https://doi.org/10.5380/rber.v4i1.42120

Ekin, Z. (2005). Resurgence of Safflower (Carthamus tinctorius L.). Utilization: A global view. Jounal of Agronomy, 4, 83-87. https://doi.org/10.3923/ja.2005.83.87 
Emongor, V. (2010). Safflower (Carthamus tinctorius L,) the underutilized and neglected crop: A review. Asian Journal of Plant Science, 9, 299-306. https://doi.org/10.3923/ajps.2010.299.306

Empresa Brasileira de Pesquisa Agropecuária (EMBRAPA). (1997). Manual de métodos de análise de solo: Centro Nacional de Pesquisa de Solos (2nd ed.). Rio de Janeiro: Embrapa.

Empresa Brasileira de Pesquisa Agropecuária (EMBRAPA). (2014). Sistema Brasileiro de Classificação de Solos (4th ed.). Brasília, DF: Embrapa.

Ferreira, D. F. (2011). Sisvar: A computer statistical analysis system. Ciência e Agrotecnologia, 35, 1039-1042. https://doi.org/10.1590/S1413-70542011000600001

Godakahriz, S. J., Rastegar, Z., \& Shahverdikandi, M. A. (2012). Effect of seed aging on safflower (Carthamus tinctorius L.) seed vigor and germination parameters. International Research Journal of Applied and Basic Sciences, 3, 445-449.

Jabeen, N., \& Ahmad, R. (2013). Variations in accessions of sunflower and safflower under stress condition. Pakistan Journal of Botany, 45, 383-389.

Karimi, N., Soheilikhah, Z., Ghasmpour, H. R., \& Zebardjadi, A. (2011). Effect of salinity stress on germination and early seedling growth of different Safflower (Carthamus tinctorius L.) genotypes. Journal of Ecobiotechnology, 3, 07-13.

Khodadad, M. (2011). An evaluation of safflower genotypes (Carthamus tinctorius L.), seed germination and seedling characters in salt stress conditions. African Journal of Agricultural Research, 6, 1667-1672. https://doi.org/10.5897/AJAR10.915

Khomari, S., Soltani-Nezhad, M., \& Sefghi, M. (2014). Effect of seed vigour and Pretreatment on Germinability and Seedling Growth of Safflower under Drought and Salinity Conditions. International Journal of Farming and Allied Sciences, 3, 1229-1233.

Limón, A., \& Peco, B. (2016). Germination and emergence of annual species and burial depth: Implications for restoration ecology. Acta Oecologica, 71, 8-13. Https://doi.org/10.1016/j.actao.2016.01.001.

Luz, F. N., Yamashita, O. M., Ferraresi, D. A., Carvalho, M. A. C., Campos, O. R., Koga, P. S., \& Massaroto, J. A. (2014). Interferência de luz, temperatura, profundidade de semeadura e palhada na germinação e emergência de Murdannia nudiflora. Comunicata Scientiae, 5, 25-33.

Maciel, C. D. G., Poletine, J. P., Velini, E. D., Zanotto, M. D., Florentino, R. S., Zani, L. P., \& Cruz, C. (2012). Desenvolvimento de cultivares de mamoneiras em relação à profundidade de semeadura e seletividade de herbicidas dinitroanilinas. Semina: Ciências Agrárias, 33, 27-38. https://doi.org/10.5433/1679-0359.2012 v33n 1 p27

Marcos-Filho, J. (2005). Fisiologia de Sementes de Plantas Cultivadas. Piracicaba: FEALQ.

Martins, C. C., Nakagawa, J., \& Bovi, M. L. A. (1991). Efeito da posição da semente no substrato e no crescimento inicial das plântulas de Palmito Vermelho (Euterpe espiritosantensis Fernandes-Palmae). Revista Brasileira de Sementes, 21, 164-173. https://doi.org/10.17801/0101-3122/rbs.v21n1p164-173

Mohammed, E. M., Benbella, M., \& Talouizete, A. (2002). Effect of sodium chloride on sunflower (Helianthus annuus L.) seed germination. Helia, 25, 51-58. https://doi.org/10.2298/HEL0237051M

Mündel, H. H., Blackshow, R. E., Byers, J. R., Huang, H. C., Johnson, D. L., \& Keon, R. (2004). Safflower production on the Canadian Prairies. Canadá: Lethbridge.

Perecin, D., \& Cargnelutti Filho, A. (2008). Efeitos por comparações e por experimento em interações de experimentos fatoriais. Ciência e Agrotecnologia, 32, 68-72. https://doi.org/10.1590/S1413-7054200800 0100010

Raven, P. H., Evert, R. F., \& Eichhorn, S. E. (2001). Biologia vegetal (6th ed.). Rio de Janeiro: Guanabara Koogan.

Rodrigues, A. J., Batista, E. M. C., Oliveira, L. M., Portella, A. C. F., \& Souza, P. B. (2016). Influência da profundidade e posição de semeadura na emergência de Acácia polyphylla DC. Revista Verde, 11, 23-29. https://doi.org/10.18378/rvads.v11i1.3812

Santos, R. F., \& Silva, M. A. (2015) Carthamus tinctorius L: uma alternativa de cultivo para o Brasil. Acta Iguazu, 4, 26-35. 
Siddiqi, E. H., Ashraf, M., \& Akram, N. A. (2007). Variation in seed germination and seedling growth in some diverse lines of safflower (Carthamus tinctorius L.) under salt stress. Pakistan Journal of Botany, 39, 1937-1944.

Silva, B. M. S., \& Cesarino, F. (2016). Germinação de sementes e emergência de plântulas de Jutaí (Hymenaea parvifolia Huber.). Revista Brasileira de Plantas Medicinais, 18, 256-263. https://doi.org/10.1590/ 1983-084X/15_178

Silva, P. R. A., Dias, P. P., Correia, T. P. S., \& Sousa, S. F. G. (2015). Emergência de plântula de milho em diferentes profundidades de semeadura. Irriga, Edição Especial, 20 anos Irriga +50 anos FCA (pp. 178-185). https://doi.org/10.15809/irriga.2015v1n1p178

Taiz, L., \& Zeiger, E. (1991). Plant physiology. Redwood City: Benjamin/Cummings Publishing Company.

Tanveer, A., Faried, M. Z., Tahir, M., Javaid, M. M., \& Khaliq, A. (2012). Environmental factors affecting the germination and seedling emergence of Carthamus oxyacantha M. Bieb. (Wild Safflower). Pakistan Journal of Weed Science Research, 18, 221-235.

Toledo, F. F. (1977). Manual das sementes: tecnologia da produção. São Paulo: Ed. Agronômica Ceres.

Torabi, B., Soltani, E., Archontoulis, S. V., \& Rabii, A. (2016). Temperature and water potential effects on Carthamus tinctorius L. seed germination: measurements and modeling using hydrothermal and multiplicative approaches. Brazilian Journal of Botany, 39, 427-436. Https://doi.org/10.1007/s40415015-0243-x

Vivas, M. J. (2002). Culturas Alternativas - Cártamo, Sésamo e Camelina. Melhoramento, 38, 183-192.

Wielewicki, A. P., Leonhardt, C., Schlindwein, G., \& Medeiros, A. C. S. (2006). Proposta de padrões de germinação e teor de água para sementes de algumas espécies florestais presentes na região sul do Brasil. Revista Brasileira de Sementes, 28, 191-197. https://doi.org/10.1590/S0101-31222006000300027

Zuffo, A. M., Andrade, F. R., Da Silva, L. M. A., Menezes, K. O., Silva, R. L., \& Piaulino, A. C. (2014). Profundidade de semeadura e superação de dormência no crescimento inicial de sementes de Brachiaria dictyoneura (Fig. \& De Not.) Stapf (1919) cv. Llanero. Revista Ceres, 61, 948-955. https://doi.org/ 10.1590/0034-737X20146106009

\section{Copyrights}

Copyright for this article is retained by the author(s), with first publication rights granted to the journal.

This is an open-access article distributed under the terms and conditions of the Creative Commons Attribution license (http://creativecommons.org/licenses/by/4.0/). 